\title{
STABILIZACJA MAKROEKONOMICZNA NA BIAŁORUSI W LATACH 2005-2014
}

Daria PILARCZYK

\section{ABSTRACT}

\section{MACRECONOMIC STABILITY IN BELARUS IN THE YEARS 2005-2014}

The economic policy of modern countries pays particular attention to the issue of macroeconomic stability which ensure sustainable growth and competitiveness. The article focuses on the situation in Belarusian economy from 2005 to 2014 in the context of macroeconomic stability. For research purposes, the author uses the method of the macroeconomic stability pentagon.

\section{KEYWORDS:}




\section{WPROWADZEN1E}

Stabilność makroekonomiczna jest ważnym elementem sprawnego i efektywnego działania gospodarki narodowej zarówno w sferze wewnętrznej, jak i na arenie międzynarodowej. Celem niniejszego artykułu będzie ukazanie sytuacji białoruskiej gospodarki w aspekcie równowagi makroekonomicznej za pomocą modelu Pięciokąta Stabilizacji Makroekonomicznej. Za okres badawczy przyjęto lata 2005-2014.

\section{TEORETYCZNE ZAGADNIENIA ZWIAZZANE ZE STABILI- ZACJA MAKROEKONOMICZNA}

Stabilność ekonomiczna rozumiana jest jako taka konfiguracja wskaźników makroekonomicznych, która pozwala na osiąganie trwałego i zrównoważonego wzrostu gospodarczego. W gospodarkach narodowych stabilność makroekonomiczna jest kształtowana poprzez politykę stabilizacyjną - jej zadaniem jest zagwarantowanie sprawnego działania systemu ekonomicznego, który w długim okresie pozwala na wzrost dochodów realnych. Rola ta jest silnie powiązana z ingerencją państwa w gospodarkę. Co więcej, podkreśla się, że celem polityki stabilizacyjnej, obejmującej kombinację polityki fiskalnej i monetarnej, jest łagodzenie wahań występujących w cyklach koniunkturalnych, co w efekcie ma także doprowadzić do równowagi makroekonomicznej².

Utrzymywanie równowagi w gospodarce związane jest z kształtowaniem pewnych wskaźników makroekonomicznych na ustalonym poziomie. Według H. Ćwiklińskiego należą do nich ${ }^{3}$ :

- roczny wzrost PKB na poziomie 3\% lub więcej;

- stopa bezrobocia nie wyższa niż 4\%;

- niska stopa inflacji w skali roku;

- stabilność kursów walutowych;

- równowaga bilansu płatniczego i równowaga budżetu państwa, występująca przy efektywnej realizacji zadań związanych z redystrybucją dochodów oraz ich alokacją w gospodarce.

G.W. Kołodko podkreśla, że w przypadku krajów postsocjalistycznych osiąganie stabilizacji związane jest $\mathrm{z}$ „przezwyciężaniem tak zwanego syndromu shortageflation,

H. Ćwikliński (red.), Polityka gospodarcza, Gdańsk 2004, s. 29-30.

R. Barczyk, Teoria i praktyka polityki antycyklicznej, Wydawnictwo Akademii Ekonomicznej w Poznaniu, Poznań 2004, s. 16.

H. Ćwikliński (red.), Polityka gospodarcza, op. cit., s. 30. 
strukturalnej cechy charakteryzującej reformowane gospodarki planowane" ${ }^{4}$. Syndrom ten, występujący jedynie w gospodarkach będących w procesie transformacji gospodarki centralnie planowanej do wolnorynkowej, związany jest ze wzrostem inflacji oraz pojawianiem się niedoborów na rynku. Według G.W. Kołodki stabilizacja makroekonomiczna powinna opierać się na pięciu elementach, warunkujących jej trwałość. Należą do nich ${ }^{5}$ :

- wzrost PKB - stagnacja i recesja w gospodarce utrudnia czy wręcz uniemożliwia osiąganie stabilności gospodarczej;

- niska stopa bezrobocia - bezrobocie wpływa negatywnie nie tylko na sytuację ekonomiczno-społeczną mieszkańców, ale także na finanse publiczne oraz politykę;

- odpowiedni poziom inflacji - umożliwiający rozwój ekonomiczny i społeczny kraju;

- zrównoważony budżet państwa lub jego nadwyżka;

- bilans obrotów bieżących utrzymywany na poziomie umożliwiającym pokrywanie spłaty zadłużenia zagranicznego.

W literaturze wskazuje się, że dla osiągania stabilizacji makroekonomicznej bardzo ważna jest równowaga zewnętrzna. Deficyt obrotów bieżących, przekraczający poziom 5\% PKB, powinien być niepokojący dla kraju jako groźba wystąpienia kryzysu walutowego $^{6}$. Wyjątek stanowią kraje rozwijające się, w których pojawia się duża potrzeba inwestowania związana ze zmianami zachodzącymi w obrębie gospodarki. Oszczędności krajowe są wtedy uzupełniane poprzez inwestycje zagraniczne. Co więcej, deficyt występujący w obrotach bieżących jest silnie powiązany z deficytem budżetu państwa z racji występowania zjawiska deficytu bliźniaczego .

Deficyt w finansach publicznych jest zjawiskiem negatywnym, które świadczy o braku oszczędności dokonywanych przez państwo. Powoduje on także, że kredyty dla przedsiębiorstw są wypierane przez kredyty dla sektora publicznego. Według porozumienia podpisanego przez państwa członkowskie Unii Europejskiej w 1997 roku w ramach Paktu Stabilności i Wzrostu, deficyt budżetowy nie powinien przekraczać $3 \% \mathrm{PKB}^{8}$.

G.W. Kołodko, Kwadratura pięciokąta [w:] P. Kozłowski, M. Wojtysiak-Kotlarski (red.), Grzegorz W. Kołodko i ćwierćwiecze transformacji, Warszawa 2014, s. 206.

Tamże, s. 206-207.

R. Barczak, L. Kąsek, M. Lubiński, K. Marczewski, Nowe oblicza cyklu koniunkturalnego, Warszawa 2006, s. 38 .

Tamże, s. 39.

https://www.nbportal.pl/slownik/pozycje-slownika/pakt-stabilnosci-i-wzrostu [dostęp: 07.04.2017]. 


\section{CHARAKTERYSTYKA METODY BADAŃ}

Do ukazania i analizy stabilizacji gospodarczej G.W. Kołodko zaproponował model Pięciokąta Stabilizacji Makroekonomicznej (PSM). Uwzględnia się w nim następujące składowe:

- stopę wzrostu PKB $(\triangle \mathrm{GDP})$;

- stopę bezrobocia $(\mathrm{U})$;

- stopę inflacji (CPI);

- saldo budżetu państwa wyrażone jako \% PKB (G);

- saldo rachunku obrotów bieżących wyrażone jako \% PKB (CA).

PSM składa się z pięciu trójkątów, z których każdy tworzony jest przez dwie wymienione wyżej zmienne (rysunek 1). Trójkąt a ukazuje dynamikę zmian PKB i stopę bezrobocia. Trójkąt b określany jest mianem trójkąta sagnacji (lub slumpflacji) $\mathrm{z}$ racji uwzględniania $\mathrm{w}$ nim stopy bezrobocia i stopy inflacji. Trójkąt $\mathbf{c}$ jest funkcją zmiany stopy inflacji oraz salda budżetu państwa, trójkąt $\mathbf{d}$ - salda budżetu państwa i salda rachunku obrotów bieżących (stąd też nazywany jest trójkątem równowagi finansowej), a trójkąt e - sektora zewnętrznego - tworzony jest poprzez wielkość salda rachunku obrotów bieżących oraz zmiany dynamiki PKB.

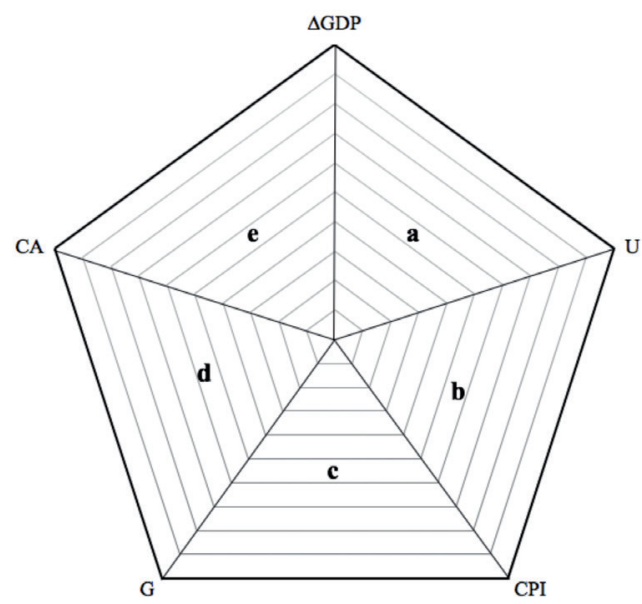

Rys. 1. Pięciokąt stabilizacji makroekonomicznej

Źródło: opracowanie własne na podstawie: G.W. Kołodko, Kwadratura pięciokąta [w:] P. Kozłowski, M. Wojtysiak-Kotlarski (red.), Grzegorz W. Kołodko i ćwierćwiecze transformacji, Warszawa 2014, s. 209. 
Wzór na obliczenie wskaźnika PSM wygląda następująco ${ }^{9}$ :

$(\Delta \mathrm{GDP} \times \mathrm{U})+(\mathrm{U} \times \mathrm{CPI})+(\mathrm{CPI} \times \mathrm{G})+(\mathrm{G} \times \mathrm{CA})+(\mathrm{CA} \times \Delta \mathrm{GDP})] \times \mathrm{k}$, gdzie k jest wartością stałą, równą 0,475 .

W trójkątach a, b oraz c uwzględniane są przede wszystkim czynniki wewnętrzne, warunkujące osiąganie przez gospodarkę stabilizacji makroekonomicznej. W trójkątach $\mathrm{d}$ oraz e analizowane są czynniki zewnętrzne. Celem tej metody jest bowiem ukazanie optymalnego wykorzystania zasobów pracy oraz wzrostu gospodarczego przy stabilizacji zachodzącej w sferze zewnętrznej i wewnętrznej, analizowanych poprzez stopę inflacji, saldo budżetu państwa oraz saldo obrotów bieżących ${ }^{10}$. Można więc zauważyć, że:

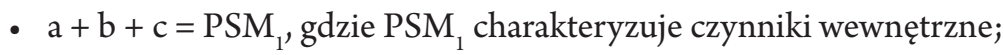

- $\mathrm{d}+\mathrm{e}=\mathrm{PSM}_{2}$, gdzie PSM $_{2}$ opisuje czynniki zewnętrzne;

- a całe pole równa się: $\mathrm{PSM}_{1}+\mathrm{PSM}_{2}=$ PSM.

Pole PSM może mieścić się w przedziale od 0 do 1 , przy czym im wyższa wartość pola, tym większa stabilizacja makroekonomiczna została osiągnięta w danej gospodarce. Stabilizacja makroekonomiczna jest bowiem możliwa poprzez osiągnięcie jak najwyższej stopy wzrostu PKB, relatywnie niskiego bezrobocia, możliwie najniższej inflacji, a także dodatnich sald budżetu państwa oraz bilansu obrotów bieżących, ukazywanych jako \% PKB.

\section{OGÓLNA CHARAKTERYSTYKA GOSPODARKI BIAŁORUSKIE] W LATACH 2005-2014}

Białoruś do 1991 roku funkcjonowała jako republika radziecka. Dopiero rozpad ZSRR spowodował, że kraj uzyskał suwerenność. Od 1994 roku urząd prezydenta w kraju sprawuje Aleksander Łukaszenko, który ukształtował autorytarny model rządów. Dysponuje on wieloma instrumentami, które umożliwiają mu sprawowanie nieograniczonej władzy w państwie: wyznacza cele polityki wewnętrznej oraz zewnętrznej, wybiera pracowników sprawujących władzę wykonawczą i sądowniczą 11. Prezydent ma także szerokie uprawnienia ustawodawcze, a przede wszystkim - dużą niezależność finansową, jego działania są bowiem finansowane z funduszy prezydenckich, które nie podlegają żadnej kontroli.

G.W.Kołodko, dz. cyt., s. 210.

10 J. Misala, Międzynarodowa konkurencyjność gospodarki narodowej, Warszawa 2011, s. 138.

J.P. Gieogrica, Biatoruś - między Polską a Rosją - konflikt czy dialog? [w:] Białoruś - między Unią Europejska a Rosjq, Warszawa 2012, s. 6. 
Polityka gospodarcza A. Łukaszenki zawiera w sobie wiele elementów gospodarki planowanej. Od czasu odzyskania niepodległości przez Białoruś nie przeprowadzano wielu reform strukturalnych, które mogłyby wpłynąć na stan ekonomiczny kraju. Na Białorusi wykorzystuje się krzyżowe subsydiowanie przedsiębiorstw państwowych - te, które przynoszą zyski, przekazują środki na utrzymywanie zakładów nierentownych. Co więcej, proces prywatyzacji przebiega powoli. W 2005 roku prawie 52\% zatrudnionych w kraju pracowało w sektorze państwowym, a 47\% - w prywatnym. W 2014 roku było to odpowiednio: $39 \%$ i $58 \%{ }^{12}$.

Białoruska gospodarka jest pod silną kontrolą administracji - przedsiębiorstwa średnie i duże (także te prywatne) otrzymują co roku wytyczne dotyczące rozwoju. Odgórnej regulacji podlegają też ceny, między innymi na towary pierwszej potrzeby ${ }^{13}$. W czasie drugiej kadencji prezydenckiej A. Łukaszenko znacznie zaostrzył regulacje. Wprowadzono tak zwaną złotą zasadę, która dawała możliwość przejmowania kontroli nad przedsiębiorstwami, niezależnie od ich struktury własności. Przepisy te zostały jednak zliberalizowane w 2008 roku w związku z trudną sytuacją gospodarczą i próbą ściągnięcia do Białorusi inwestorów zagranicznych ${ }^{14}$.

W 2008 roku, wobec pogorszenia sytuacji ekonomicznej w kraju, Międzynarodowy Fundusz Walutowy postawił Białorusi warunek udzielenia kredytu - rozpoczęcie reform zmierzających do liberalizacji gospodarki. Wówczas rząd Białorusi przygotował plan określający główne kierunki rozwoju społeczno-ekonomicznego, prowadzące do gospodarki wolnorynkowej (dotyczyly one między innymi regulacji cen, stosunków majątkowych, ustaw antymonopolowych). Pomimo kredytu w wysokości 3,5 miliardów dolarów amerykańskich, udzielonego przez MFW, większość założeń zawartych w planie nie została zrealizowana ${ }^{15}$.

Pod względem wolności gospodarczej Białoruś wypada słabo w porównaniu do innych krajów Europy. Według Wskaźnika Wolności Gospodarczej (Index of Economic Freedom, IEF), przygotowywanego od 1995 roku przez Heritage Foundation, w 2014 roku na 178 krajów Białoruś zajęła 150. miejsce, uzyskując 50,1 punktów. Lider tego rankingu, Hongkong, został oceniony na 90,1 punktów, czyli o 40 punktów więcej niż Białoruś. Wśród krajów europejskich gorzej wypadła tylko Ukraina. Dla porównania, w 2005 roku gospodarka białoruska została oceniona na 46,7 punktów.

\footnotetext{
http://www.belstat.gov.by/en/ofitsialnaya-statistika/social-sector/trud/godovye-dannye/number-ofemployed-by-ownership-types/ [dostęp: 07.04.2017].

L. Złotnikow, Biatoruski model ekonomiczny - forma, treść, efektywność [w:] M. Iwanow (red.), Biatoruś: dalsza droga do demokracji, Wroctaw 2011, s. 64.

14 K. Falkowski, Międzynarodowa konkurencyjność gospodarek Białorusi, Rosji i Ukrainy, Warszawa 2013, s. 194.

L. Złotnikow, dz. cyt., s. 66
} 
Najniżej w 2014 roku oceniono na Białorusi wolność finansową, poszanowanie praw własności oraz wolność od korupcji. Te dwa ostanie subwskaźniki odnoszą się do sfery instytucjonalnej państwa i warunkują jego konkurencyjność na rynkach międzynarodowych. Warto wspomnieć, że subwskaźnik „wolność od korupcji” podlegał dużym wahaniom w omawianych latach 2005-2014, co świadczy o nieskuteczności wprowadzanych regulacji w tym obszarze. Niskie oceny wolności finansowej wynikają z faktu, że białoruskie banki funkcjonują jako własność państwowa.

Warto wspomnieć, że białoruska gospodarka jest silnie uzależniona od dostaw gazu i ropy naftowej z Rosji. Od lat dziewięćdziesiątych XX wieku pozycja Białorusi była uprzywilejowana - ceny na dostawy tych surowców były stosunkowo niskie w porównaniu do cen nałożonych przez Rosję na inne kraje, co pozwalało Białorusi na produkcję niższym kosztem. W produkcji nadal utrzymuje się tendencja ukształtowana w czasach istnienia Związku Radzieckiego - w wewnątrzzwiązkowym podziale pracy gospodarka białoruska pełniła rolę „ostatniego ogniwa”, a większość surowców była dostarczana $\mathrm{z}$ innych republik radzieckich.

W 2006 roku doszło jednak do podwyższenia cen na gaz dla Białorusi i mimo że nie była ona tak drastyczna, jak początkowo zakładano, silnie dotknęła gospodarkę kraju. Co więcej, zbiegło się to z kryzysem naftowym - wtedy też Rosja zmieniła politykę importową ropy naftowej na Białoruś, nakładając cła. Wcześniej bowiem Białoruś nie ponosiła żadnych dodatkowych opłat, co - przy eksporcie przetworzonej ropy w białoruskich rafineriach do krajów trzecich - przynosiło znaczne wplywy do białoruskiego budżetu ${ }^{16}$.

Uzależnienie Białorusi od Rosji nie wynika tylko z dostaw surowców energetycznych. Rosja jest głównym partnerem handlowym Białorusi, a także sojusznikiem militarnym. Wpływa na to przede wszystkim położenie Białorusi między sferą wpływów NATO i Unii Europejskiej a Rosją. Ponadto na terytorium Białorusi znajdują się rosyjskie bazy wojskowe.

Od momentu upadku Związku Radzieckiego Białoruś jest uczestnikiem ugrupowań gospodarczych, powstających pod przewodnictwem Rosji. Należy między innymi do Wspólnoty Niepodległych Państw czy funkcjonującej od 2015 roku Euroazjatyckiej Unii Gospodarczej.

W. Konończuk, Trudny „sojusznik” - Białoruś w polityce Rosji, Warszawa 2008, s. 15-16, http://www.osw. waw.pl/sites/default/files/pw_34_bialorus_pl_net.pdf [dostęp: 02.04.2017]. 


\section{ANALIZA WYBRANYCH WSKAŹNIKÓW MAKROEKONOMICZNYCH}

W latach 2005-2008 wzrost gospodarczy wyrażony poprzez przyrost PKB w stosunku do roku poprzedniego na Białorusi był relatywnie wysoki i wahał się w granicach 8-10\%. W 2009 roku doszło do zahamowania dynamicznego wzrostu, co było po części skutkiem światowego kryzysu gospodarczego - zmniejszył się popyt na białoruskie towary na rynkach zagranicznych oraz pojawiły się ograniczenia w pozyskiwaniu zewnętrznego finansowania.

Odpowiedzią rządu na spowolnienie gospodarcze było wprowadzenie restrykcyjnej polityki makroekonomicznej oraz regulacje kursu walutowego. W 2010 roku wzrost PKB wyniósł 7,74\% - ożywienie spowodowane było rządowym programem pożyczek, który doprowadził jednak do niekorzystnej sytuacji wzrostu inflacji i spadku wartości rubla białoruskiego. Wpłynęło to na spowolnienie dynamiki wzrostu PKB w kolejnych latach.

Stopa bezrobocia w białoruskiej gospodarce w latach 2005-2014 była stosunkowo niska (w porównaniu do krajów Unii Europejskiej, a także takich jak Rosja czy Ukraina). We wszystkich badanych latach kształtowała się na poziomie poniżej 2\%, a w latach 2009-2014 była niższa niż 1\%. Wynika to z polityki zatrudnienia, prowadzonej na Białorusi - w państwowych przedsiębiorstwach funkcjonuje wiele zbytecznych etatów, a realna stopa bezrobocia może być nawet kilkakrotnie wyższa. Przedsiębiorstwa te są jednak dotowane z budżetu państwa, a ich brak rentowności nie wiąże się $\mathrm{z}$ bankructwem.

\begin{tabular}{|c|c|c|c|c|c|}
\hline Rok & $\mathbf{\Delta G D P}$ & $\mathbf{U}$ & $\mathbf{C P I}$ & $\mathbf{G}$ & CA \\
\hline 2005 & 9,4 & 1,7 & 10,3 & $-6,6$ & 1,5 \\
\hline 2006 & 10,0 & 1,4 & 7,0 & $-6,6$ & $-3,8$ \\
\hline 2007 & 8,6 & 1,1 & 8,4 & $-8,9$ & $-6,7$ \\
\hline 2008 & 10,2 & 1,0 & 14,8 & $-10,7$ & $-8,2$ \\
\hline 2009 & 0,2 & 0,9 & 12,9 & $-19,2$ & $-12,5$ \\
\hline 2010 & 7,7 & 0,8 & 7,7 & $-19,6$ & $-15,0$ \\
\hline 2011 & 5,5 & 0,7 & 53,2 & $-40,8$ & $-8,5$ \\
\hline 2012 & 1,7 & 0,6 & 59,2 & $-25,2$ & $-2,9$ \\
\hline 2013 & 1,1 & 0,5 & 18,3 & $-24,6$ & $-10,4$ \\
\hline 2014 & 1,7 & 0,5 & 18,1 & $-25,4$ & $-3,8$ \\
\hline
\end{tabular}




\section{Tabela 1. Wybrane wskaźniki makroekonomiczne Białorusi w latach 2005-2014}

\section{Żródło: Bazy danych Banku Światowego oraz Międzynarodowego Funduszu Walutowego.}

Co więcej, na Białorusi rozwinięty jest system świadczenia odpłatnych prac społecznych - każda osoba bezrobotna ma więc możliwość podjęcia zatrudnienia, niezależnie od tego, czy przyniesie to korzyści dla gospodarki. W 2015 roku A. Łukaszenko podpisał dekret prezydencki, na mocy którego osoby, które nie przepracowały w ciągu roku kalendarzowego 183 dni, podlegają karze grzywny. Wyjątek stanowią niepełnoletni oraz emeryci.

Inflacja na Białorusi w latach 2005-2014 podlegała dużym wahaniom - w 2012 roku wynosiła prawie $60 \%$. W pierwszej dekadzie XXI wieku po raz pierwszy od ogłoszenia suwerenności kraju inflacja przyjęła wartości jednocyfrowe. W latach dziewięćdziesiątych XX wieku inflacja sięgała ponad $2000 \%$. Wynikało to przede wszystkim ze zmian, jakie zaszły w sferze rubla rosyjskiego po rozpadzie ZSRR. Przejęcie prowadzenia polityki pieniężnej i obniżanie poziomu inflacji na Białorusi nie leżały w interesie władz - rozliczenia z Rosją musiałyby bowiem odbywać się po cenach światowych. Wyemitowano więc bony, które funkcjonowały na rynku równolegle z rublami rosyjskimi, wywołując silną presję inflacyjną ${ }^{17}$.

W latach 2005-2014 na Białorusi notowano rokroczny deficyt budżetowy. W okresie 2005-2006 stanowił on 6,6\% PKB, ale od 2008 roku udział ten regularnie wzrastał i w 2011 roku wynosił 40,8\% PKB wygenerowanego przez gospodarkę narodową. W kolejnych latach 2012-2014 deficyt budżetowy był stosunkowo stabilny, utrzymując się na poziomie około 25\% PKB kraju.

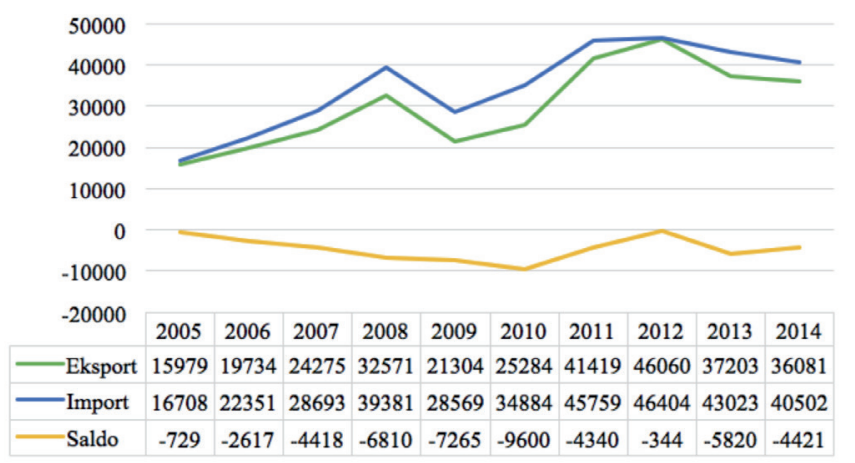

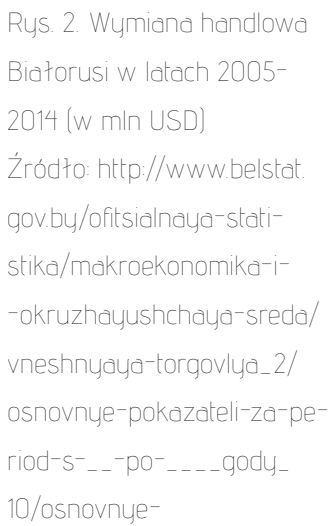

pokazateli-vneshnei-torgovil/ [dostęp: 02.04.2017].

17 D. Eberhardt, Gra pozorów: stosunki rosyjsko-białoruskie 1991-2008, Warszawa 2008, s. 121-124. 
W analizowanym okresie jedynie w 2005 roku zanotowano dodatnie saldo obrotów bieżących, równe 1,5\% PKB kraju. W następnych latach było ono ujemne najwyższy deficyt w stosunku do PKB, równy 15\%, zanotowano w 2010 roku. Było to związane z rokroczną przewagą wartości importu nad eksportem (rysunek 2).

Głównymi partnerami handlowymi Białorusi są kraje Wspólnoty Niepodległych Państw, do których, oprócz Białorusi, zaliczane są: Azerbejdżan, Armenia, Kazachstan, Kirgistan, Mołdawia, Rosja, Tadżykistan, Turkmenistan, Uzbekistan oraz Ukraina. W 2014 roku wartość eksportu Białorusi wyniosła 36 mld dolarów amerykańskich, z czego ponad 21 mld dolarów to produkty eksportowane do krajów WNP - stanowiło to $58 \%$ eksportu ogółem. Import w 2014 roku był równy prawie 41 mld dolarów, z czego z krajów WNP importowano produkty o wartości przekraczającej 24 mld dolarów. Wśród krajów WNP największym partnerem handlowym Białorusi była Federacja Rosyjska - w 2014 roku eksport z Rosji stanowił 42\% całego eksportu, a import - prawie 55\% całości.

\section{ANALIZA STABILIZACJI MAKROEKONOMICZNEJ NA BIA ŁORUSI W LATACH 2004-2015 Z WYKORZYSTANIEM METODY PSM}

W celu opracowania pięciokątów stabilizacji makroekonomicznej dla Białorusi w latach 2004-2015 wzięto pod uwagę wartości minimalne i maksymalne przyjmowane przez poszczególne wskaźniki, a także sytuację ekonomiczną w krajach podobnych do Białorusi, takich jak Rosja czy Ukraina. Zastosowane skale przedstawiają się następująco:

- dla $\Delta \mathrm{GDP}$ - od $0 \%$ do $11 \%$;

- dla U - od $8 \%$ do $0 \%$;

- dla CPI - skala logarytmiczna w przedziale od 5 do 0;

- dla $\mathrm{G}$ - od $-41 \%$ do $0 \%$;

- dla CA - od - $16 \%$ do $2 \%$.

W okresie 2005-2014 wystąpiła duża rozbieżność w wartościach wskaźnika PSM (rysunek 3). Największym polem PSM w badanych latach charakteryzował się rok 2005 - było one równe 0,6639 . W kolejnych latach wartości regularnie spadały, aż do 2009 roku, kiedy to pole PSM wyniosło 0,1666. W 2010 roku wartość ta była równa 0,3085 . 


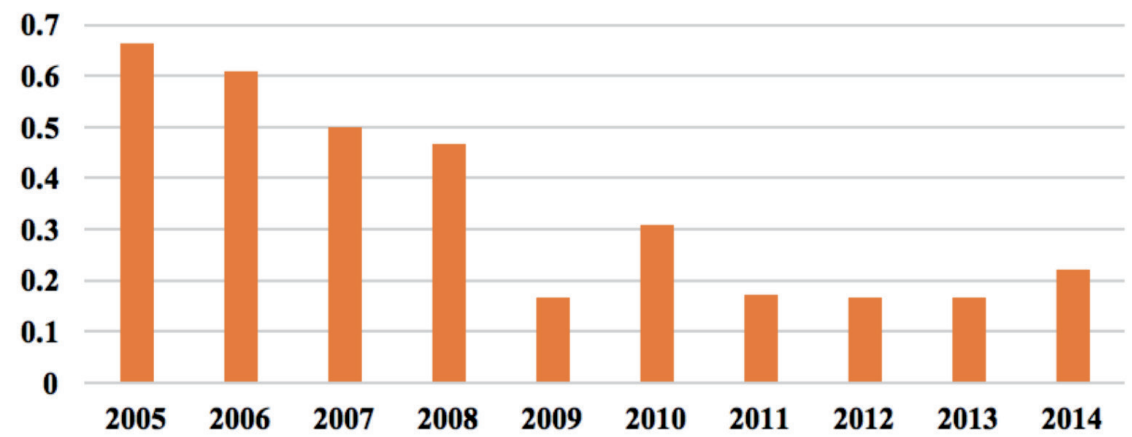

\section{Rys. 3. Wskaźnik PSM dla Białorusi w latach 2005-2014 \\ Żródło: Obliczenia własne}

W 2011 roku wartość pola PSM dla Białorusi wyraźnie spadła, szczególnie w porównaniu do lat 2005-2006. Najniższe wartości w analizowanym okresie osiągnięto jednak w kolejnych dwóch latach, kiedy to wskaźnik PSM w 2012 roku był równy 0,1651, a w 2013 roku - 0,1650. W 2014 roku PSM było równe 0,2218.

Analiza wartości PSM dla poszczególnych lat z rozróżnieniem na sferę wewnętrzną i zewnętrzną pokazuje, że najniższa wartość w aspekcie wewnętrznym $\left(\mathrm{PSM}_{1}\right)$ w latach 2005-2014 wystąpiła w 2012 roku i była równa 0,0769. Najwyższa wartość PSM równa 0,3508 została przypisana dla 2006 roku, co było związane z wysoką stopą wzrostu PKB $\mathrm{w}$ danym roku oraz najniższym poziomem inflacji, zanotowanym w badanym okresie. W latach 2005-2008 pole PSM przyjmowało wartości powyżej 0,3000. Wynikało to w dużej mierze z wysokich wartości, uzyskiwanych przez trójkąt sfery realnej (trójkąt a). W 2009 roku zanotowano wyraźny spadek tempa wzrostu w porównaniu do lat poprzednich, co wpłynęło na zmniejszenie pola trójkąta a.

\begin{tabular}{|c|c|c|c|c|c|c|c|c|}
\hline Rok & $\mathrm{a}$ & $\mathrm{b}$ & $\mathrm{c}$ & $\mathrm{d}$ & $\mathrm{e}$ & PSM1 & PSM2 & PSM \\
\hline 2005 & 0,1337 & 0,0834 & 0,0894 & 0,1912 & 0,1661 & 0,3065 & 0,3574 & 0,6639 \\
\hline 2006 & 0,1489 & 0,0999 & 0,1021 & 0,1334 & 0,1235 & 0,3508 & 0,2569 & 0,6078 \\
\hline 2007 & 0,1352 & 0,0992 & 0,0897 & 0,0951 & 0,0811 & 0,3241 & 0,1762 & 0,5003 \\
\hline 2008 & 0,1628 & 0,0809 & 0,0681 & 0,0754 & 0,0807 & 0,3118 & 0,1561 & 0,4678 \\
\hline
\end{tabular}




\begin{tabular}{|c|c|c|c|c|c|c|c|c|}
\hline 2009 & 0,0032 & 0,0863 & 0,0519 & 0,0245 & 0,0007 & 0,1414 & 0,0252 & 0,1666 \\
\hline 2010 & 0,1262 & 0,1060 & 0,0616 & 0,0068 & 0,0079 & 0,2938 & 0,0147 & 0,3085 \\
\hline 2011 & 0,0923 & 0,0376 & 0,0002 & 0,0006 & 0,0422 & 0,1301 & 0,0428 & 0,1729 \\
\hline 2012 & 0,0289 & 0,0338 & 0,0141 & 0,0654 & 0,0228 & 0,0769 & 0,0882 & 0,1651 \\
\hline 2013 & 0,0182 & 0,0780 & 0,0334 & 0,0293 & 0,0061 & 0,1296 & 0,0354 & 0,1650 \\
\hline 2014 & 0,0293 & 0,0788 & 0,0319 & 0,0605 & 0,0213 & 0,1400 & 0,0818 & 0,2218 \\
\hline
\end{tabular}

\section{Tabela 2. Wskaźniki PSM gospodarki białoruskiej w latach 2005-2014.}

\section{Żródło: Obliczenia własne.}

W kolejnych latach niskie wartości osiągało pole trójkąta $\mathrm{c}$ - związane to było z występowaniem wysokiej inflacji i deficytu budżetowego. Najniższe pole trójkąta c, równe 0,0002, zanotowano w 2011 roku, kiedy to inflacja była równa 53,2\%, a saldo budżetu stanowiło $-40,8 \%$ PKB.

W latach 2005-2010 rokrocznie spadała wartość wskaźnika PSM charakteryzującego strefę zewnętrzną gospodarki. W 2005 roku pole PSM było równe 0,3574, a w 2010 r. - 0,0147. W 2009 roku pole trójkąta e było szczególnie niskie, równe 0,007, czego przyczyn upatrywać można w kryzysie gospodarczym, który dotknął światową gospodarkę, powodując spadek dynamiki wzrostu PKB Białorusi do $0,2 \%$ oraz zmniejszenie popytu na białoruskie towary na rynkach zagranicznych.

$\mathrm{Na}$ rysunku 4, gdzie graficznie zaprezentowano pięciokąty stabilizacji makroekonomicznej dla białoruskiej gospodarki, zaobserwować można rokroczne zmiany, jakie zachodziły w kraju w aspekcie osiągania stabilizacji makroekonomicznej w analizowanym okresie. Od 2007 roku widoczna była postępująca destabilizacja makroekonomiczna kraju, zachodząca szczególnie w przypadku trójkąta równowagi finansowej (trójkąta d) oraz trójkąta równowagi zewnętrznej (trójkąt e). W 2010 roku nastąpiła pewna poprawa w aspekcie stabilizacyjnym w porównaniu do lat wcześniejszych, ale dotyczyła ona głównie sfer wewnętrznych gospodarki. W latach 2011-2013 po raz kolejny zaobserwowano negatywne zmiany, wpływające destabilizacyjnie na sytuację makroekonomiczną kraju. Szczególnie niekorzystny kształt wykres przyjął w 2013 roku. 

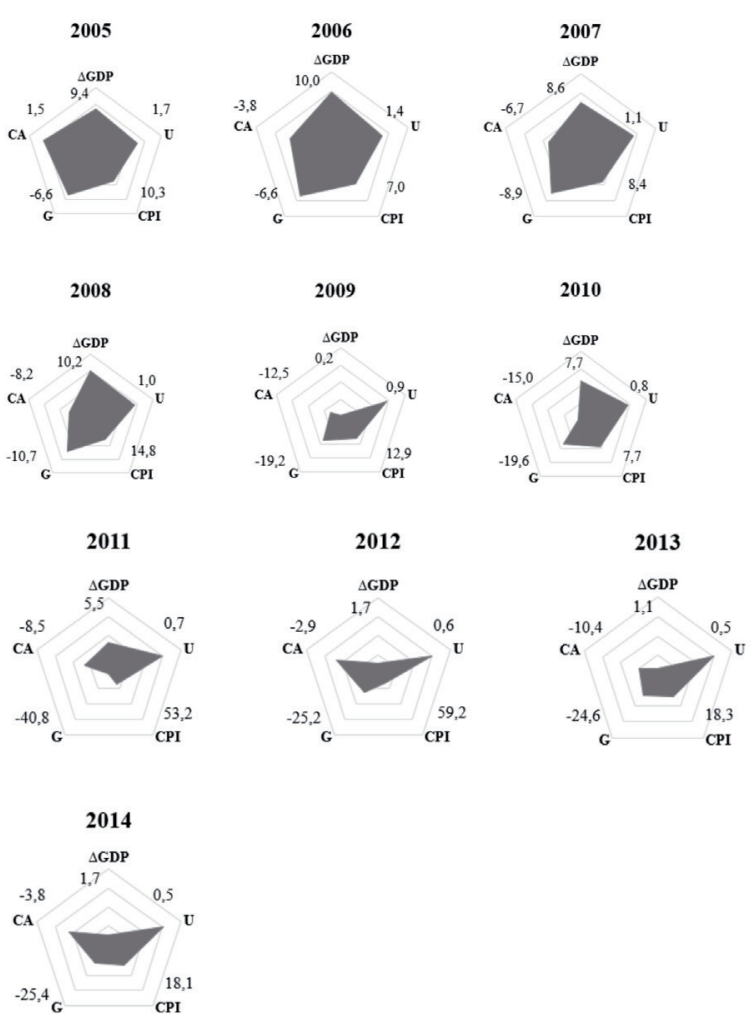

\section{PODSUMOWAN $1 E$}

W analizowanym okresie, przypadającym na lata 2005-2014, występowała wyraźna destabilizacja białoruskiej gospodarki w aspekcie makroekonomicznym, widoczna szczególnie od 2007 roku. Wpływ na to miało szereg czynników, pojawiających się zarówno po stronie wewnętrznej, jak i zewnętrznej. Bez wątpienia przyczyną problemu jest brak odpowiednich działań w zakresie polityki monetarnej i fiskalnej, a także silne uzależnienie gospodarcze od Rosji. W badanych latach miał miejsce światowy kryzys ekonomiczny, który także negatywnie wpłynął na sytuację makroekonomiczną na Białorusi. W 2014 roku zaobserwowano niewielki wzrost wskaźnika PSM w stosunku do lat wcześniejszych, ale konieczne będą dalsze badania w celu nakreślenia tendencji i perspektyw zmian w kolejnych okresach. 


\section{BIBLIOGRAFIA}

Barczak R., Kąsek L., Lubiński M., Marczewski K., Nowe oblicza cyklu koniunkturalnego, Warszawa 2006;

Barczyk R., Teoria i praktyka polityki antycyklicznej, Poznań 2004;

Baza danych Departamentu Statystyki Białorusi, http://www.belstat.gov.by/ ofitsialnaya-statistika/makroekonomika-i-okruzhayushchaya-sreda/vneshnyayatorgovlya_2/osnovnye-pokazateli-za-period-s-__-po-___ gody_10/osnovnyepokazateli-vneshnei-torgovli/ [dostęp: 02.04.2017];

Baza danych Departamentu Statystyki Białorusi, http://www.belstat.gov.by/en/ ofitsialnaya-statistika/social-sector/trud/godovye-dannye/number-of-employed-byownership-types/ [dostęp: 07.04.2017];

Ćwikliński H. (red.), Polityka gospodarcza, Gdańsk 2004;

Falkowski K., Międzynarodowa konkurencyjność gospodarek Białorusi, Rosji i Ukrainy, Warszawa 2013;

Gieogrica J.P., Białoruś - między Polska a Rosją - konflikt czy dialog? [w:] Białoruś - między Unia Europejska a Rosja, Warszawa 2012;

Kołodko G.W., Kwadratura pięciokąta [w:] P. Kozłowski, M. Wojtysiak-Kotlarski (red.), Grzegorz W. Kołodko i ćwierćwiecze transformacji, Warszawa 2014;

Konończuk W., Trudny „sojusznik” - Białoruś w polityce Rosji, Warszawa 2008, http://www.osw.waw.pl/sites/default/files/pw_34_bialorus_pl_net.pdf [dostęp: 02.04.2017];

Misala J., Międzynarodowa konkurencyjność gospodarki narodowej, Warszawa 2011;

Strona internetowa Narodowego Banku Polskiego, https://www.nbportal.pl/ slownik/pozycje-slownika/pakt-stabilnosci-i-wzrostu [dostęp: 07.04.2017];

Złotnikow L., Białoruski model ekonomiczny - forma, treść, efektywność [w:] M. Iwanow (red.), Białoruś: dalsza droga do demokracji, Wrocław 2011. 